\title{
Fondo Andaluz de Recuperación del Conocimiento Artesano
}

EI Proyecto FARCA, desarrollado en los años 2002-2003, partió de una iniciativa de la Consejería de Economía de la Junta de Andalucía en pro de la recopilación de los oficios artesanos tradicionales en peligro de extinción, encaminada a la salvaguarda de sus conocimientos a través de su catalogación e incorporación a un banco de imágenes. Se documentaron, por tanto, artesanías de las que hoy pervive un único representante en toda Andalucía, otras con un número muy escaso de talleres en activo y otras con mayor proporción pero con la constancia de la avanzada edad de sus practicantes.

Siguiendo la filosofía de los Tesoros Culturales Vivos, resulta evidente que si sólo se conserva el objeto, los secretos de su elaboración morirán junto con sus últimos practicantes. De ahí la urgencia de recoger esos procesos productivos: cada una de las técnicas de producción, el uso de las materias primas, las diferentes herramientas utilizadas, así como los modos característicos que cada artesano ha ido adquiriendo de sus antepasados y readaptando a las exigencias de su tiempo.

En esta línea, la premisa que guió la investigación fue que la inmensa mayoría de estas actividades, convenientemente encauzadas, pueden encontrar un sólido acomodo en el sistema económico vigente, tras el obligado reajuste de muchos de los patrones tradicionales a las exigencias que la dinámica cultural va marcando. Todo elemento cultural vivo precisa de una continua adaptación a los nuevos contextos sociales, artesanía incluida, aunque por su estrecha asociación a lo "popular" y a lo "tradicional", se le atribuya falsamente la cualidad del inmovilismo. En definitiva, lo que se persiguió fue la preservación y puesta en valor de unas prácticas artesanas de evidente interés, tanto cultural por ser sólidos exponentes del legado patrimonial de todos los andaluces, como económico por su capacidad para generar empleo y riqueza.

El banco de imágenes realizado debería servir para revitalizar estas artesanías al promover su conocimiento y divulgar sus valores en los más diversos ámbitos y foros de interés, a la vez que podría contribuir a la formación de nuevos artesanos al brindárseles la oportunidad de observar con detalle esas técnicas productivas, hoy en riesgo de desaparición.

No obstante, no se agotaban ahi las posibles repercusiones del proyecto, pues habían de ser otros muchos los beneficios derivados del mismo:

$\rightarrow$ Mejorar el nivel de información sobre la situación real de la artesanía andaluza, para posibilitar el diseño de un marco de actuación y la implementación de acciones para su desarrollo y consolidación.

$\rightarrow$ Incidir en las políticas específicas que hagan viable eliminar las causas que obligan a muchos artesanos a ampararse en la economía sumergida, cuando no al cierre de sus talleres.

$\rightarrow$ Motivar a los agentes implicados en el sector ayudando a crear una conciencia colectiva entre los artesanos de que la artesanía es una actividad económica de futuro, con grandes posibilidades de desarrollo.

$\rightarrow$ Facilitar la cohesión sectorial y territorial de los artesanos andaluces, creando la conciencia de la necesidad de colaboración y asociación entre ellos y avanzando hacia su vertebración eficaz.

De lo que estamos convencidos es de que nada positivo se conseguirá si, junto al avance de los pertinentes programas políticos para la reactivación del sector, los esfuerzos no se encaminan a la concienciación social del valor de la artesanía, entendiéndola como el medio más eficaz para su preservación. Justo ésta es la contribución que se derivaría de la exhibición de los documentales realizados: en exposiciones y ferias comerciales, en casas de oficios y escuelas-taller y, por supuesto, en los medios de difusión masiva a través de emisiones televisivas. Sólo así podrá visualizarse la complejidad de unas técnicas de trabajo con las que se va dando forma a unos productos tan específicos y diferenciales que han llegado a convertirse en verdaderos modelos identitarios de una determinada población.

Esther Fernández de Paz

Departamento de Antropología Social. Universidad de Sevilla 